\title{
Research Paper Total factor productivity growth of cumin crop in Gujarat: Measurement and determinants
}

See end of the paper for authors' affiliations

Correspondence to : B. Swaminathan Department of Agricultural Economics, Junagadh Agricultural University, Junagadh (Gujarat) India

Email : bswaminathan @jau.in

Paper History :

Received : 12.11.2018;

Revised : 28.01.2019;

Accepted : 08.02.2019
ABSTRACT : The study has examined the growth in total factor productivity (TFP) of cumin crop and its sources in Gujarat state from 1990-91 to 2011-12 using Tornqvist Theil index. The findings revealed higher growth rates of output indices $(2.13 \%)$ and moderate growth rates of TFP indices $(1.48 \%)$ per annum, duringthe study period. Besides, the investment on cumin research was also found to have generated aninternal rate of return of 74.90 per cent. This indicates the possibility of cumin playing animportant role of enhancing farm incomes in Gujarat. Further, government expenditure on agricultural research and education, extension education and development of ground water as well as canal irrigation in Gujarat were found to have positive and significant impact on TFP. The study suggest that the growth in TFP can further be enhanced and sustained through varietal improvements in cumin crop and expanding irrigation coverage.

KEY WORDS : Cumin, TFP, Research contribution, IRR

How To Cite This PAper : Dhandhalya, M.G., Tarpara, V.D., Swaminathan, B. and Chavda, Haresh (2019). Total factor productivity growth of cumin crop in Gujarat: Measurement and determinants . Internat. Res. J. Agric. Eco. \& Stat., 10 (1) : 68-74, DOI : 10.15740/HAS/IRJAES/10.1/68-74. Copyright@ 2019: Hind AgriHorticultural Society. 